\title{
Fuel-independent and membrane-less self-charging biosupercapacitor
}

Pankratov, Dmitry; Shen, Fei; Ortiz, Roberto; Toscano, Miguel D.; Thormann, Esben; Zhang, Jingdong; Gorton, Lo; Chi, Qijin

Published in:

Chemical Communications

Link to article, DOI:

10.1039/C8CC06688D

Publication date:

2018

Document Version

Peer reviewed version

Link back to DTU Orbit

Citation (APA):

Pankratov, D., Shen, F., Ortiz, R., Toscano, M. D., Thormann, E., Zhang, J., Gorton, L., \& Chi, Q. (2018). Fuelindependent and membrane-less self-charging biosupercapacitor. Chemical Communications, 54(83), 1180111804. https://doi.org/10.1039/C8CC06688D

\section{General rights}

Copyright and moral rights for the publications made accessible in the public portal are retained by the authors and/or other copyright owners and it is a condition of accessing publications that users recognise and abide by the legal requirements associated with these rights.

- Users may download and print one copy of any publication from the public portal for the purpose of private study or research.

- You may not further distribute the material or use it for any profit-making activity or commercial gain

- You may freely distribute the URL identifying the publication in the public portal

If you believe that this document breaches copyright please contact us providing details, and we will remove access to the work immediately and investigate your claim 


\section{Accepted Manuscript}

This article can be cited before page numbers have been issued, to do this please use: D. Pankratov, F. Shen, R. Ortiz, M. D. Toscano, E. Thormann, J. Zhang, L. Gorton and Q. Chi, Chem. Commun., 2018, DOI: 10.1039/C8CC06688D.
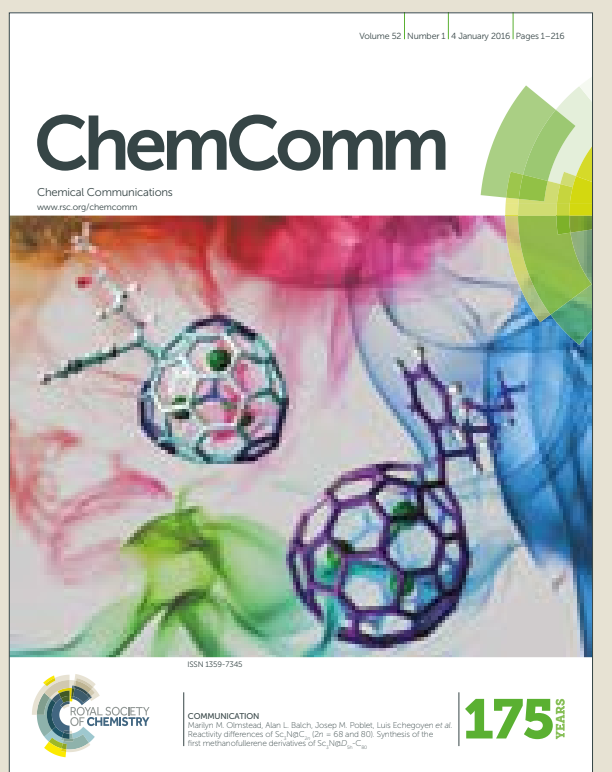

This is an Accepted Manuscript, which has been through the Royal Society of Chemistry peer review process and has been accepted for publication.

Accepted Manuscripts are published online shortly after acceptance, before technical editing, formatting and proof reading. Using this free service, authors can make their results available to the community, in citable form, before we publish the edited article. We will replace this Accepted Manuscript with the edited and formatted Advance Article as soon as it is available.

You can find more information about Accepted Manuscripts in the author guidelines.

Please note that technical editing may introduce minor changes to the text and/or graphics, which may alter content. The journal's standard Terms \& Conditions and the ethical guidelines, outlined in our author and reviewer resource centre, still apply. In no event shall the Royal Society of Chemistry be held responsible for any errors or omissions in this Accepted Manuscript or any consequences arising from the use of any information it contains. 


\section{ChemComm}

\section{Fuel-independent and membrane-less self-charging biosupercapacitor}

Received 00th January 20xx, Accepted 00th January 20xx

DOI: $10.1039 / x 0 x x 00000 x$

\author{
Dmitry Pankratov, ${ }^{* \mathrm{a}}$ Fei Shen, ${ }^{\mathrm{a}}$ Roberto Ortiz, ${ }^{\mathrm{a}}$ Miguel Duarte Toscano, ${ }^{\mathrm{b}}$ Esben Thormann, ${ }^{\mathrm{a}}$ \\ Jingdong Zhang, ${ }^{a}$ Lo Gorton ${ }^{c}$ and Qijin Chi ${ }^{{ }^{a}}$
}

www.rsc.org/

We present a fuel-independent self-charging biosupercapacitor comprising an oxygen reducing enzymatic biocathode and an opposing bioelectrode, in which the supercapacitive properties of immobilised protein were utilised. Our findings disclose a novel hybrid type of bioelectrochemical systems, which can potentially be employed as autonomous power suppliers in substratedeficient conditions.

The rapidly differentiating field of portable and autonomous miniature electronics operating under ex vivo and in vivo conditions requires power sources capable of efficient operation in close contact with physiological fluids or inside the human body.

Enzymatic fuel cells (EFCs) are bioelectrochemical devices, which directly convert chemical energy into electric power, while fuel and oxidant are continuously supplied to the electrodes. As distinct from the conventional fuel cells, where employment of abiotic catalysts usually requires harsh environment for efficient operation (e.g. strong acidic or basic media, high temperature), EFCs are capable to function at human physiological $\mathrm{pH}$ and temperature. EFCs utilize enzymes (oxidoreductases) to facilitate oxidation or/and reduction reactions occurring on the bioanode and biocathode, respectively. These miniature power sources enable delivering power densities up to several $\mathrm{mW} \mathrm{cm}{ }^{-2}{ }^{1}$ and attract specific attention as autonomous power suppliers for implantable or disposable medical devices for monitoring of diseases during short periods up to several months. ${ }^{2}$ The performance of EFCs was examined in vivo in rats, ${ }^{3}$ rabbits ${ }^{4-5}$ and ex vivo in human blood, ${ }^{6}$ demonstrating the perspectives of their practical application.

In spite of all possible advantages of EFCs, they cannot be efficiently applied, when the concentration of oxidant or/and fuel is not sufficient to provide satisfactory power output or performance of the electrode is underachieved to establish the necessary level of chemical energy conversion. Several strategies have been proposed to overcome these restrictions. Switching from continuous to intermittent mode in supercapacitive EFCs allows accumulation of charge during long-term low-power operation, which can be instantaneously extracted in short high-power pulses. ${ }^{7-8}$ Another approach is related to the development of hybrid devices, where a lowperformance bioelectrode can be replaced with a rechargeable battery-type or pseudocapacitive abiotic electrodes based on Prussian Blue, ${ }^{9} \mathrm{Ag}_{2} \mathrm{O} / \mathrm{Ag}^{10}$ or $\mathrm{MnO}_{2}{ }^{11}$ for the cathodic side. However, any practical long-term applicability of inorganic materials in implantable conditions is debatable due to the inflammatory response and possible poisoning with leaking heavy metal ions. Recently a novel concept, denoted proteinbased biosupercapacitors (BSCs), has been demonstrated by Mosa et al., ${ }^{12}$ where different protein films were layer-by-layer assembled with reduced graphene oxide. Biomodification with protein leads to a significant enhancement of the electrode capacitance due to adsorption/desorption of electrolyte ions and protonation/deprotonation of the amino acid side chains. The potential employment of surface-confined acid/base reactions of organic molecules for charge-storing purposes has also been recently demonstrated. ${ }^{13}$ Since the processes determining the charge-storing features of immobilised protein molecules are reversible, one can expect the recovery of the electrical double layer structure after the discharging pulse, i.e. so-called self-charging behavior, previously reported for enzyme-based electrodes, rapidly recharging after current pulses or when an external load was applied. ${ }^{8}$

\footnotetext{
a. Department of Chemistry, Technical University of Denmark, DK-2800 Kongens Lyngby, Denmark.E-mail: ca@kemi.dtu.dk (Q.C.), dmpp@kemi.dtu.dk (D.P.) b. Protein Diversity, Novozymes A/S, Krogshojvej 36, 2880 Bagsvaerd, Denmark

c. Department of Biochemistry and Structural Biology, Lund University, P.O. Box 124, SE-22100 Lund, Sweden

† Electronic Supplementary Information (ESI) available: Methods, Fig. S1-S4. See DOI: $10.1039 / x 0 x x 00000 x$
} 

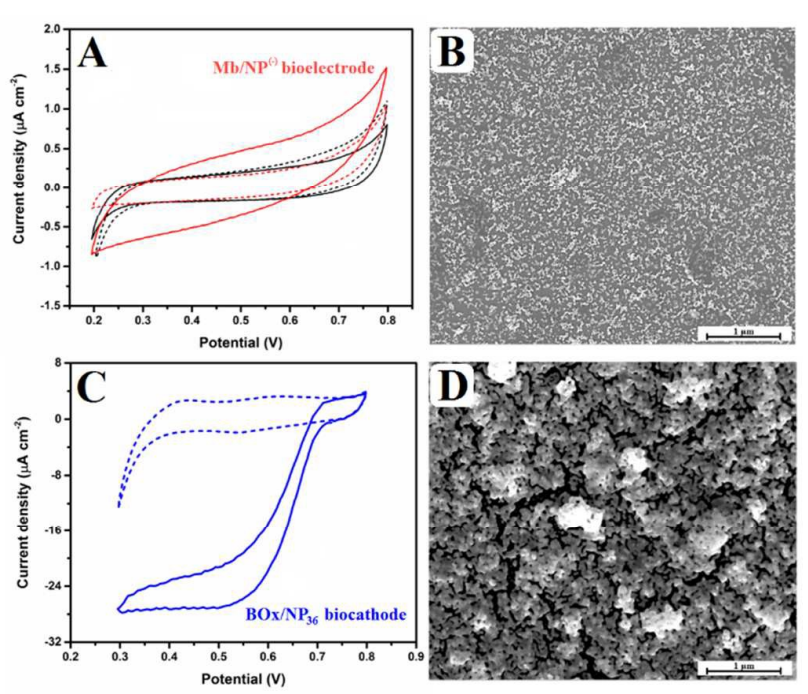

Fig. 1 (A, C) Typical cyclic voltammograms of bare (dashed curves) and biomodified (solid curves) $\mathrm{NP}^{(-)}$(red curves), $\mathrm{NP}^{(+)}$(black curves) and $\mathrm{NP}_{36}$ (blue curves) electrodes in air saturated $\mathrm{PB}(\mathrm{pH} 7.5)$, scan rate $5 \mathrm{mV} \mathrm{s}^{-1}$. (B, D) Scanning electron microscopy images of a glassy carbon electrode modified with $N P^{(-)}(B)$ and $\mathrm{NP}_{36}$ electrochemically treated in $0.5 \mathrm{M}$ $\mathrm{H}_{2} \mathrm{SO}_{4}$ (D); magnification: $\times 50000$.

In this work, we aimed to develop a self-charging bioelectrode based on the supercapacitive properties of myoglobin $(\mathrm{Mb})$ immobilised on the surface of functionalised gold nanoparticles (AuNPs) to substitute a fuel-dependent bioanode in a conventional charge-storing EFC operating in a pulse mode for potential application under implantable or wearable conditions. $\mathrm{Mb}$ has a significant ratio of charged residue/molar mass, which determines a higher capacitance of $\mathrm{Mb}$-based electrodes compared to bioelectrodes based on hemoglobin, cytochrome $c$, glucose oxidase and catalase. ${ }^{12}$ Being a neutral protein with an isoelectric point close to $7.0,{ }^{14}$ $\mathrm{Mb}$ has an overall negative charge at $\mathrm{pH}$ 7.5. To create the very first example of a hybrid bioelectrochemical device, combining energy-converting and electrostatic supercapacitive rechargeable bioelectrodes, an Mb/AuNPs electrode has been further coupled with a biocathode based on bilirubin oxidase (BOx), inversely charged due to oxygen reducing activity of immobilised enzyme.

AuNPs with an average size of $9.2\left(\mathrm{NP}_{9}\right)$ and of $35.9 \mathrm{~nm}\left(\mathrm{NP}_{36}\right)$ determined by atomic force microscopy (Fig. S1, ESI + ) were prepared by the common citrate-reduction procedure. Asprepared $\mathrm{NP}_{9}$ were electrostatically coated with polycations polyethyleneimine $\left(\mathrm{NP}^{(+)}\right)$or poly(allylamine hydrochloride) with a subsequent coverage with polyanion poly(sodium 4styrenesulfonate) $\left(\mathrm{NP}^{(-)}\right)$to obtain a positively or a negatively charged surface in neutral media following previously reported protocols. ${ }^{15}$ Detailed description of the experimental procedures is provided in the Supporting Information.

$\mathrm{Mb}$ was immobilised on glassy carbon electrodes modified with $N \mathrm{P}^{(-)}$or $\mathrm{NP}^{(+)}$to create diverse surface charges for suitable protein orientation. Both $\mathrm{NP}^{(-)}$and $\mathrm{NP}^{(+)}$modified electrodes have comparable capacitance of $30 \pm 2$ and $35 \pm 2 \mu \mathrm{F} \mathrm{cm}$, respectively, in an air-saturated $12 \mathrm{mM}$ phosphate buffer

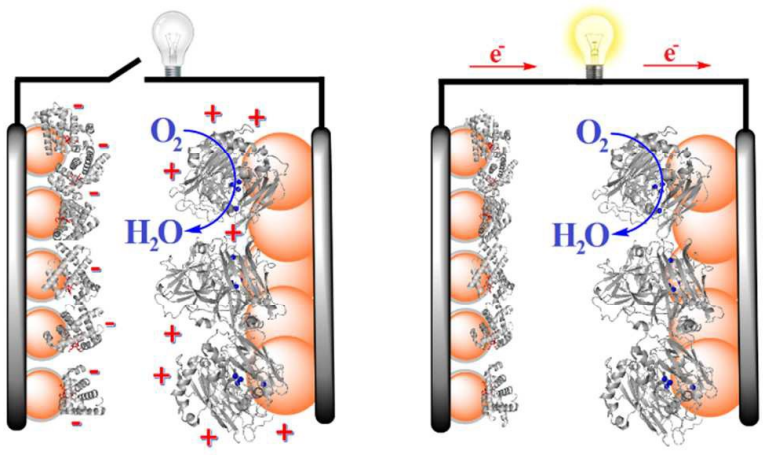

Scheme 1. Schematic representation of the assembled fuel-independent and membrane-less self-charging biosupercapacitor in self-charging and discharging states (left and right, respectively). The structures of $\mathrm{Mb}$ and BOx were created using PDB 3WFT and 2XLL, respectively.

solution containing $137 \mathrm{mM} \mathrm{NaCl}$ and $2.7 \mathrm{mM} \mathrm{KCl}(\mathrm{PB}, \mathrm{pH} 7.5)$, which was used as the electrolyte for all electrochemical experiments (Fig. 1A). The relatively low capacitance values were attributed to the sub-monolayer coverage of coated $\mathrm{NP}_{9}$ (Fig. 1B) used to distinguish any possible pseudocapacitive features of the charged AuNP surface suitable for adsorption/desorption of the ions from the supporting electrolyte and the charge-storing features of $\mathrm{Mb}$ itself. Biomodification of $\mathrm{NP}^{(-)}$with $\mathrm{Mb}$ leads to a growth of the electrode capacitance up to $82 \pm 5 \mu \mathrm{F} \mathrm{cm}{ }^{-2}$, in contrast to the biomodified $\mathrm{NP}^{(+)}$electrodes, where a 1.1-fold reduction of the electrode capacitance was indicated. Utilization of the denatured $\mathrm{Mb}$ results in a significant decrease in the capacitance compared to the native protein (Fig. S2A, ESIt), confirming correlation between the protein structure and electrostatic features. The distinctive rectangular shape of the cyclic voltammogram (CV) indicates a typical pseudocapacitive behavior of the immobilised protein, similar to Mb-modified graphene electrodes, ${ }^{12}$ azurin-modified $\mathrm{Au}(111)$ electrodes ${ }^{16}$ and some inorganic materials, such as $\mathrm{RuO}_{2}$ or $\mathrm{MnO}_{2}{ }^{17}$

To assemble a fuel-independent membrane-less self-charging biosupercapacitor (SCBSC), a Mb-modified $\mathrm{NP}^{(-)}$bioelectrode $\left(\mathrm{Mb} / \mathrm{NP}^{(-)}\right)$possessing no anodic bioelectrocatalytic ability (Fig. $\mathrm{S} 3, \mathrm{ESI}+$ ) was combined with an oxygen-reducing biocathode based on BOx, adsorbed on a highly developed threedimensional gold matrix (Fig. 1D) of $\mathrm{NP}_{36}$ treated in $0.5 \mathrm{M}$ sulfuric acid (Scheme 1). Since the capacitance of the biocathode was 4.8 -fold higher than that for the Mb-modified $N \mathrm{P}^{(-)}$electrode (Fig. 1C), the charge-storing ability of the hybrid biodevice was limited by the $\mathrm{Mb} / \mathrm{NP}^{(-)}$. Utilization of threedimensional BOx/AuNPs biocathodes for bioelectrocatalytic oxygen reduction has been well established in recent works related to supercapacitive enzymatic fuel cells ${ }^{18}$ and biosolar cells $^{19}$ and thoroughly evaluated in a recent review by Mano and de Poulpiquet, ${ }^{20}$ therefore a detailed investigation of its performance was beyond the scope of this particular paper. The open circuit voltage (OCV) of the SCBSC in equilibrium state was $0.42 \pm 0.03 \mathrm{~V}$, corresponding to the fully charged biocathode (open circuit potential (OCP) of $0.72 \pm 0.01$ ) and 


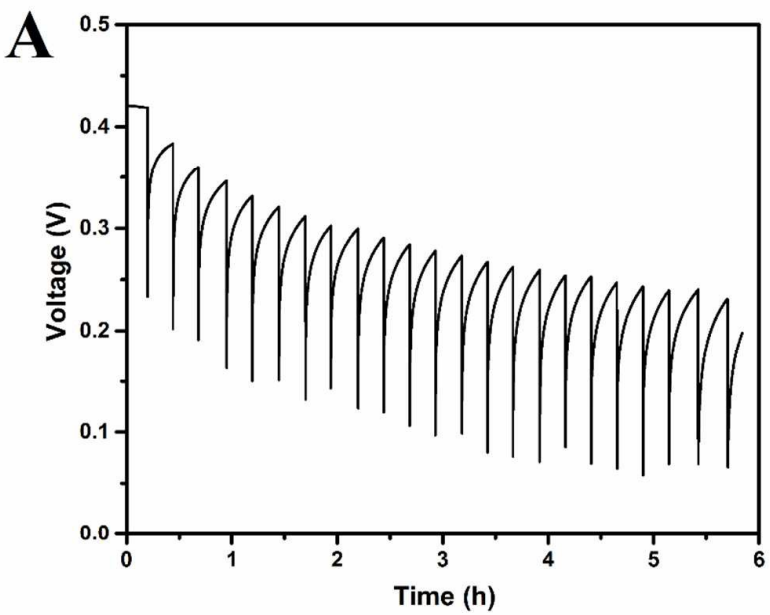

B

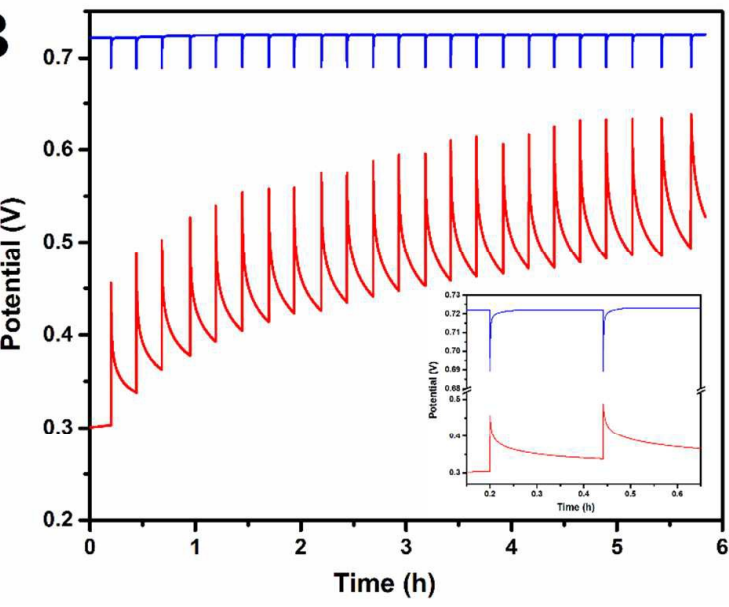

Fig. 2 Representative charge/discharge curves of the SCBSC (A) and separate electrodes (B), enzymatic biocathode (blue curve) and a protein bioanode (red curve), in air saturated PB ( $\mathrm{pH} 7.5$ ). Discharge was carried out by applying a pulse current of $10 \mu \mathrm{A} \mathrm{cm}^{-2}$ for $1 \mathrm{~s}$. Inset in (B): magnification of initial charge/discharge cycles.

$\mathrm{Mb} / \mathrm{NP}^{(-)}$(OCP of $0.30 \pm 0.02 \mathrm{~V}$ ) (Fig. 2). The OCV value achieved in this work is close to the OCV of most examples of supercapacitive EFCs, ${ }^{18,21-23}$ but $0.15 \mathrm{~V}$ higher compared to a supercapacitive glucose/oxygen EFC intended to operate at micromolar concentrations of fuel. ${ }^{24}$ The stabilised SCBSC was discharged by applying a current pulse of $10 \mu \mathrm{A} \mathrm{cm}{ }^{-2}$ for $1 \mathrm{~s}$, which leads to a voltage drop of $0.19 \pm 0.02 \mathrm{~V}$, which remains constant for at least 20 following cycles of continuous charge/discharge operation. The overall capacitance of the SCBCS calculated from fast galvanostatic discharge was $25 \%$ lower than the expected value considering the capacitance of the separate bioelectrodes calculated from CVs, following a common antithetical correlation between the capacitance and scan (or discharge) rate for pseudocapacitive materials. ${ }^{25}$ An average peak power output of $c a .3 \mu \mathrm{W} \mathrm{cm}$ achieved for the fuel-independent membrane-less SCBSC is similar to that for lactate/oxygen $\mathrm{EFCs}^{26-27}$ and glucose/oxygen EFCs designed for operation at low concentrations of fuel. ${ }^{28-29}$
The self-recharging process was carried out for $900 \pm 30 \mathrm{~s}$ after the pulse was applied and led to a $91 \%, 98 \%$ and $99 \%$ recovery of the OCV after the $1^{\text {st }}, 10^{\text {th }}$ and $20^{\text {th }}$ discharging pulses, respectively, indicating a dynamic stabilization of the performance of the SCBCS on an OCV of $c a$. $0.24 \mathrm{~V}$ (Fig. 2). This OCV value obtained for the fuel-independent SCBCS is twice as high as the value achieved in a recent report in the presence of glucose, ${ }^{24}$ demonstrating the advantages of the proposed concept over conventional EFCs adapted to operate in the pulse mode.

Taking into account that a low potential drop during the discharging process and the oxygen reducing activity determine the rapid recovery of the OCP of the cathode, the self-recharging ability and stability of the assembled SCBSC are mainly determined by the $\mathrm{Mb} / \mathrm{NP}^{(-)}$(Fig. 2B). Since there were no significant changes in the capacitance, this suggests that no $\mathrm{Mb}$ desorption occurred during the experiments, but rather a gradual flattening and compression of the enzyme layer could be considered as the origin of the decrease in the OCV value (and growth of OCP of the $\mathrm{Mb} / \mathrm{NP}^{(-)}$), similarly to the effect demonstrated for the biocathodes based on BOx physisorbed on the Au surface. ${ }^{30}$

The design of a supercapacitive protein electrode based on a sub-monolayer coverage with AuNPs can easily be adapted to create transparent electrodes to substitute enzymatic bioanodes for potential utilization without any significant losses in transparency (Fig. S4, ESI+), in contrast to reported analogues. $^{24,26-27}$

Taking into account the concept of a self-rechargeable protein electrode and the fuel-independent SCBCS presented herein, it should be emphasised that classification of biosupercapacitors into conventional and self-charging based on their operational principles $^{8}$ cannot be justified. Even the so-termed conventional BSCs possess complete or a particular ability to recover their surface charge in solution not only due to "active" enzymatic energy conversion ability, but also because of "passive" electrostatic equilibration, therefore classification of biological power sources to energy converting, charge storing and hybrid devices looks more reasonable, taking into account recent progress in the field. Energy converting systems, viz. conventional and supercapacitive EFCs, photobioelectrochemical cells, are designed for irreversible conversion of light or chemical energy into electric power and require substrates for operation, charge-storing BSCs and biobatteries employ electrostatic, pseudocapacitive or faradaic properties of immobilised biomaterials for reversible chargestoring purposes, whereas hybrid devices combine electrodes of different types, such as the SCBCS presented in this work. In conclusion, the present study has revealed a novel concept of a fuel-independent and membrane-less self-charging biosupercapacitor, combining an enzymatic biocathode employing the oxygen-reducing activity of $\mathrm{BOx}$ and a protein electrode gaining the advantages of the pseudocapacitive properties of immobilised Mb. The characteristics of the SCBCS achieved in pulse mode together with a notable operational stability compared to recently reported analogues, allow to consider this kind of hybrid biological power source as a 
possible alternative to conventional and supercapacitive EFCs, which require substrates for active charging of enzymatic electrodes.

The findings reported herein may be a significant step towards development of more efficient and biocompatible biological power sources and self-powered biosensors intermittently operating in physiological fluids under lack of fuel, e.g. in tears or saliva. ${ }^{31}$ Furthermore, such an approach opens new perspectives of employment of human proteins as a bioelement in supercapacitive electrodes for potentially implantable hybrid bioelectrochemical systems with reduced inflammatory response, where redox enzymes (and human oxidoreductases in particular) cannot be efficiently utilised for energy conversion purposes.

DP acknowledges the People Programme (Marie Curie Actions) of the European Union's Seventh Framework Programme (FP7/2007-2013) under REA grant agreement no. 609405 (COFUNDPostdocDTU). LG thanks the Swedish Research Council (project 2014-5908), RO, QC and JZ acknowledge the Danish Council for Independent Research (Project ID: Multifunction anti-fouling bioactive surfaces, DFF 5054-00196; DFFFTP 12-127447 and the YDUN project, DFF 4093-00297, respectively). FS is grateful for the $\mathrm{PhD}$ scholarship from China Scholarship Council (CSC 201506170059).

\section{Conflicts of interest}

There are no conflicts to declare.

\section{Notes and references}

1 C. H. Kwon, S. H. Lee, Y. B. Choi, J. A. Lee, S. H. Kim, H. H. Kim, G. M. Spinks, G. G. Wallace, M. D. Lima, M. E. Kozlov, R. H. Baughman and S. J. Kim, Nat. Commun., 2014, 5, 3928.

2 S. Cosnier, A. J. Gross, F. Giroud and M. Holzinger, Curr. Opin. Electrochem., 2018, DOI: 10.1016/j.coelec.2018.06.006.

3 P. Cinquin, C. Gondran, F. Giroud, S. Mazabrard, A. Pellissier, F. Boucher, J.-P. Alcaraz, K. Gorgy, F. Lenouvel, S. Mathé, P. Porcu and S. Cosnier, PLoS One, 2010, 5, e10476.

4 S. El Ichi-Ribault, J.-P. Alcaraz, F. Boucher, B. Boutaud, R. Dalmolin, J. Boutonnat, P. Cinquin, A. Zebda and D. K. Martin, Electrochim. Acta, 2018, 269, 360-366.

5 T. Miyake, K. Haneda, N. Nagai, Y. Yatagawa, H. Onami, S. Yoshino, T. Abe and M. Nishizawa, Energy Environ. Sci., 2011, 4, 5008-5012.

6 D. Pankratov, L. Ohlsson, P. Gudmundsson, S. Halak, L. Ljunggren, Z. Blum and S.Shleev, RSC Adv., 2016, 6, 7021570220.

7 C. Agnès, M. Holzinger, A. Le Goff, B. Reuillard, K. Elouarzaki, S. Tingry and S. Cosnier, Energy Environ. Sci., 2014, 7, 18841888.

8 S. Shleev, E. González-Arribas and M. Falk, Curr. Opin. Electrochem., 2017, 5, 226-233.

9 X. Xie, M. Ye, C. Liu, P.-C. Hsu, C. S. Criddle and Y. Cui, Energy Environ. Sci., 2015, 8, 546-551.

10 Y. Yu, M. Xu, L. Bai, L. Han and S. Dong, Biosens. Bioelectron., $2016,75,23-27$.

11 X. Xiao, P. Ó Conghaile, D. Leech, R. Ludwig and E. Magner, Biosens. Bioelectron., 2017, 98, 421-427.
12 I. M. Mosa, A. Pattammattel, K. Kadimisetty, P. Pande, M. F. El-Kady, G. W. Bishop, M. Novak, R. B. Kaner, A. K. Basu, C. V. Kumar and J. F. Rusling, Adv. Energy Mater., 2017, 1700358.

13 S. Gan, L. Zhong, L. Gao, D. Han and L. Niu, J. Am. Chem. Soc., 2016, 138, 1490-1493.

14 M. Graf, R. G. García and H. Wätzig, Electrophoresis, 2005, 26, 2409-2417.

15 M. Tavahodi, R. Ortiz, C. Schulz, A. Ekhtiari, R. Ludwig, B. Haghighi and L. Gorton, Chempluschem, 2017, 82, 546-552.

16 Q. Chi, J. Zhang, J. U. Nielsen, E. P. Friis, I. Chorkendorff, G. W. Canters, J. E. T. Andersen and J. Ulstrup, J. Am. Chem. Soc., 2000, 122, 4047-4055.

17 T. Brousse, D. Belanger and J. W. Long, J. Electrochem. Soc., 2015, 162, A5185-A5189.

18 D. Pankratov, Z. Blum, D. B. Suyatin, V. O. Popov and S. Shleev, ChemElectroChem, 2014, 1, 343-346.

19 G. Pankratova, D. Pankratov, K. Hasan, H.-E. Åkerlund, P.-Å. Albertsson, D. Leech, S. Shleev and L. Gorton, Adv. Energy Mater., 2017, 7, 1602285.

20 N. Mano and A. de Poulpiquet, Chem. Rev., 2018, 118, 23922468.

21 S. Alsaoub, A. Ruff, F. Conzuelo, E. Ventosa, R. Ludwig, S. Shleev and W. Schuhmann, Chempluschem, 2017, 82, 576583.

22 D. Pankratov, F. Conzuelo, P. Pinyou, S. Alsaoub, W. Schuhmann and S. Shleev, Angew. Chem. Int. Ed., 2016, 55, 15434-15438.

23 X. Xiao, P. Ó Conghaile, D. Leech, R. Ludwig and E. Magner, Biosens. Bioelectron., 2017, 90, 96-102.

24 T. Bobrowski, E. González Arribas, R. Ludwig, M. D. Toscano, S. Shleev and W. Schuhmann, Biosens. Bioelectron., 2018, 101, 84-89.

25 G. Otrokhov, D. Pankratov, G. Shumakovich, M. Khlupova, Y. Zeifman, I. Vasil'eva, O. Morozova and A. Yaropolov, Electrochim. Acta, 2014, 123, 151-157.

26 R. C. Reid, S. D. Minteer and B. K. Gale, Biosens. Bioelectron., 2015, 68, 142-148.

27 X. Xiao, T. Siepenkoetter, P. Ó Conghaile, D. Leech and E. Magner, ACS Appl. Mater. Interfaces, 2018, 10, 7107-7116.

28 M. Falk, V. Andoralov, M. Silow, M. D. Toscano and S. Shleev, Anal. Chem., 2013, 85, 6342-6348.

29 E. González-Arribas, T. Bobrowski, C. Di Bari, K. Sliozberg, R. Ludwig, M. D. Toscano, A. L. De Lacey, M. Pita, W. Schuhmann and S. Shleev, Biosens. Bioelectron., 2017, 97, 46-52.

30 D. Pankratov, R. Sundberg, J. Sotres, D. B. Suyatin, I. Maximov, S. Shleev and L. Montelius, Beilstein J. Nanotechnol., 2015, 6, 1377-1384.

31 A. J. Bandodkar and J. Wang, Electroanalysis, 2016, 28, 11881200. 